\title{
Understanding Consumer Receptiveness of Mortgage-Based Islamic Social Finance Using a Maqasid Framework: A Preliminary Study
}

\author{
Hanudin Amin* \\ Universiti Malaysia Sabah, Malaysia, hanudin@ums.edu.my
}

Article History

Received: May 29, 2019 Revised: June 18, 2019 Accepted: July 8, 2019

\begin{abstract}
This study proposes a workable model of the mortgage-based Islamic social finance (MBISF) and to test the model acceptance using a maqasid framework empirically. Three battery items are intended to measure each latent variable. As for independent variables, the latent variables are an educational programme, mortgage welfare, consumer justice and Islamic debt policy, whilst as for a dependent variable, the latent variable is consumer receptiveness. Using Structural Equation Modelling (SEM) - Partial Least Squares or SEM-PLS, this study finds out that educational programme, mortgage welfare, consumer justice and Islamic debt policy are instrumental to lead the consumer receptiveness of MBISF. These results suggest that the elements of maqasid al-Shariah (education, welfare, justice and debt policy) are significant to consumer receptiveness of MBISF. The relationships established are then called as The Maqasid Theory of Consumer Behaviour (MTCB). Though the present work produced a fruitful outcome, yet the generalisation of the findings is somewhat limited and the application of the theory used in consumer behaviour is relatively fallen short or even unpopular in the conventional thinking. The results obtained provide better planning for Islamic banks to market their mortgages effectively.
\end{abstract}

Keywords: Mortgage-Based Islamic Social Finance, Islamic Social Bank, Maqasid, Affordable Financing.

JEL Classification: G21; D11; D12

@ IJIEF 2019 published by Universitas Muhammadiyah Yogyakarta, Indonesia All rights reserved

DOI:

https://doi.org/10.18196/ijief.2115
Web:

http://journal.umy.ac.id/index.php/ijief/article/view/6337

Citation:

Amin, H. (2019). Understanding Consumer Receptiveness of Mortgage-Based Islamic Social Finance Using a Maqasid Framework: A Preliminary Study. International Journal of Islamic Economics and Finance (IIIEF), 2(1),47-72. Doi: https://doi.org/10.18196/ijief.2115.

\footnotetext{
* Corresponding author: Labuan Faculty of International Finance, Associate Professor Dr., Universiti Malaysia Sabah, Labuan International Campus, Malaysia, E-mail: hanudin@ums.edu.my
} 
Amin | Understanding Consumer Receptiveness of Mortgage-Based Islamic Social Finance Using a Maqasid Framework: A Preliminary Study

\section{Introduction}

By definition, a mortgage is a legal agreement in which a consumer house purchase is typically financed by an Islamic bank while the former repays the latter that includes (principal + profit) as written in the mortgage agreement. In a mortgage transaction, the bought house is collateral to secure the financing obtained (Abdul-Razak \& Abduh, 2012). As for Islamic banks, mortgage financing is a secured and stable portfolio due to constant monthly repayment by homebuyers (i.e. debtors). As for homebuyers, the financing facility provides a financial resource to improve their homeownership but also requires a long term financial commitment and for that their well-being of family members is, somehow, affected. Indeed, payment for home mortgage normally takes a good chunk of one's monthly income (Mydin-Meera \& Abdul-Razak, 2005; Hasan, 2011). Islamic home financing products are an important segment of Islamic banking products, contributing to the market share of 36.6 per cent for Islamic total financing in Malaysia whilst the rest is controlled by conventional loans, amounting 63.4 per cent of the total financing exist in the banking industry in Malaysia (Bank Negara Malaysia, 2018). Although imperative, the growth of Islamic home financing is somehow unpredictable due to inconsistency in consumer receptiveness that is driven by many factors. One of the possible reasons is the imitation of Islamic home financing products in which the features are analogous to their conventional peers out of lending and borrowing principle and public misconception (Abdul-Razak \& Abduh, 2012).

As a preliminary idea, the present work intends to suggest a new form of mortgage to be called as mortgage-based Islamic social finance (MBISF), that can be offered by Islamic banks but the emphasis is on the social benefits, exceeding the profit generation of the banks since the funding is generated from non-liability sources like zakat and awqaf. Besides, there is a growing interest by scholars in Islamic home financing to promote a more socialoriented Islamic home financing. For instance, two works by Zabriet al. (2015) and Zabri and Mohammed (2018) examine the offering of Shariahcompliant mortgage financing by financial cooperatives and a Cash WaqfFinancial Cooperative-Musharakah Mutanaqisah home financing model, respectively. The message of these works is to convey an important idea pertinent to improved homeownership among needy and poor using innovative Islamic home financing facilities without compromising the financial returns of Islamic banks.

This article, however, considers the need for MBISF in the context of Malaysia to support by zakat, awqaf and sadaqah for existence and sustainability. As such, the term mortgage-based Islamic social finance is defined as the mortgage facility offered to low and moderate-income

IJIEF: International Journal of Islamic Economics and Finance, 2(1), 47-72 | 48 
Amin | Understanding Consumer Receptiveness of Mortgage-Based Islamic Social Finance Using a Maqasid Framework: A Preliminary Study

families who are in need of homeownership for improved well-being. This idea, however, is mixed blessings.

There are three (3) reasons why this mortgage is vital for households:

- Firstly, inequality of wealth distributions. The Gini index can be employed to explain the social gap in which the score of 0 representing 100 per cent perfect equality while the score of 1 demonstrating 100 per cent inequality. Department of Statistics Malaysia (2016) reports that the Gini index for urban and rural areas was 0.391 and 0.355, respectively. In Labuan and Sabah, the reported index was 0.390 , implying there exists income disparity between households;

- Secondly, the house and land prices. Owing to the income disparity as mentioned, the ability of an individual to purchase a complete house or land for a house is difficult. In the past, an intermediate terrace house cost RM200,000-RM300,000 which was affordable to the medium-income groups. Today, however, the price of the house can reach up to RM1 million. This trend, however, is quite alarming. In Labuan, Malaysia alone, the price of a single storey terrace house is estimated around RM350,000-RM500,000, implying a level that is difficult to fulfil by the low-income group to make a house purchase. In fact, the prediction of the increased price of houses among local folks has also contributed to the increased price for the house. For instance, some parents buy houses today for their children to improve their children homeownership in the future. In turn, the house prices are affected out of contemporary demand by parents; and

- Thirdly, a bank's aptitude in approving the mortgage's applications. There was evidence saying that some people blame a bank for declining their financing applications. In real practice, however, the bank has put its best effort to approve the customer application for maslahah to avoid the latter to get trapped into an acute indebtedness. Those earning RM3,000 - RM5,000 have a greater risk if they think for a better home that costs them a price of RM500,000. Consumers existing financial obligations such as car and personal financing are some reasons why their applications are rejected to avoid themselves trapped in bad debts.

This study expounds at least four (4) features of MBISF as follows:

- Firstly, absolute ownership. The ownership of the mortgage and the house are surely owned by Allah (SWT). Hence, the transacting parties should promote integrity, fairness, honesty and faith in God. Consequently, the element of piety in the mortgage is of importance

IJIEF: International Journal of Islamic Economics and Finance, 2(1), 47-72 | 49 
Amin | Understanding Consumer Receptiveness of Mortgage-Based Islamic Social Finance Using a Maqasid Framework: A Preliminary Study

to secure its purpose in providing financial assistance to needy for home ownership instead of profit maximisation. The mortgage proposed is aimed at maximising pahala of all parties involved, at least;

- Secondly, relationships of the transacting parties. The relationships that generate are significantly in extending financial resources to enable the poor and needy to get their first homeownership. The concept of brotherhood and ihsan are extended;

- Thirdly, the exclusion of all forms of interest in financial transactions. The element of interest charges is excluded including its "implication"; and

- Fourthly, the sources of knowledge. The mortgage-based Islamic social finance is prescribed in the Quran in the support of wellbeing and inner peace. In the Quran (Al-Maidah: 5:2), Allah (Azza WaJalla) said "...Help ye one another in righteousness and piety, but help ye not one another in sin and rancour..." implying mortgage-based Islamic social finance is about to help needy and poor along with an effort to generate sufficient profit for continuity.

In all, this paper aims to examine factors determining receptiveness of consumer of MBISF. For this purpose, the Theory of Maqasid Consumer Behaviour (TMCB) is developed to capture the distinctiveness of mortgagebased Islamic social finance.

\section{Literature Review and Maqasid Theory of Consumer Behaviour}

\section{Theory}

Maqasid theory tells us about the inter-relationship from one occurrence to another. In my opinion, the theory provides answers to queries of how and why. It explains about the event about why behaviour takes place and how it happens. Typically, theory in Islamic banking literature is stemmed from the primary sources of Islam, which are of interest to protect one's tawheed, akhlaq and figh for the benefit of all parties involved. It is of an assertion that a maqasid theory is a good theory that can provide a better explanation, prediction and measurement of consumer receptiveness of Islamic banking products like in the case of a tawarruq-based mortgage.

The term maqasid al-Shariah refers to an objective of Shariah that gives a balanced deliberation on one's life, religion, intellect, property and lineage. Choudhury (1986) offers an insightful concept of maqasid al-Shariah through the confirmation about a universal goal and specific applications that can be

IJIEF: International Journal of Islamic Economics and Finance, 2(1), 47-72 | 50 
Amin | Understanding Consumer Receptiveness of Mortgage-Based Islamic Social Finance Using a Maqasid Framework: A Preliminary Study

built on this goal to attain the hierarchy of values in Islamic law. For instance, homeownership is categorised under property in the maqasid. Auda (2010) refers maqasid to a purpose, objective, principle, intent and goal, among others. In this regard, the objectives of Shariah are of three. The first is to educate individual, the second is to establish justice and the third is to realize public interest covering all individuals to serve ummah better. After all, the Quran and the Hadith are the sources that explain why maqasid alShariahis needed in our society.

Maqasid al-Shariah plays a vital rule to offer a Shariahparameter in upholding fair financial transactions involving banks and customers. Dusuki (2008) supports an assertion that maqasid can jack up the quality of justice in social financial transactions. A well-known scholar, Chapra (2000) asserts the significance of balancing the measures between individuals' interest and ummah's interest to meet the maqasid and for that, the vision of the religion can be attained. The two visions are the promotion of socio-economic justice and well-being of individuals.

Chapra (2000) suggest that the Islamic banking objectives should be at firstly (1) promoting social welfare or obligation of individuals or consumers, and secondly (2) to optimise the earning that can be drawn from their interaction with consumers at large in order to actualise the maqasid alShariah in Islamic banking. Chapra (2000) has influenced Dusuki (2008) in the proposal of what are objectives of Islamic banks. Dusuki (2008) provides empirical support which of these objectives is essential, firstly, profit obligation, and, secondly social obligation. He discovers that the latter plays as a primary objective of Islamic banks. These include the responsibilities to take up the welfares of their staff, customers and the general public. This also means that profit should come after social obligation takes place to promote the maqasid and for that it becomes a competitive banking weapon for Islamic social banks.This is also in light with Kamali's (2008) viewpoint who stresses the importance of fairness in terms of justice, removal of prejudice and assuaging hardship in one's action.

Chapra (1992) asserts that maqasid al-Shariah is related to Islamic business activity to fulfil falah and well-being of individuals. It is also needed to promote ethical practices among individual in society. A work by Richardson (2011) provides support to Chapra's (1992) theory. The author confirms the significance of equity promotion, justice, no exploitation and protection of individual wealth and also the promotion of clean and ethical standards of doing social interactions. The inability of Islamic banks to apply these measures can be of a reason why their performance is still lagged behind compared with their conventional peers.

IJIEF: International Journal of Islamic Economics and Finance, 2(1), 47-72 | 51 
Amin | Understanding Consumer Receptiveness of Mortgage-Based Islamic Social Finance Using a Maqasid Framework: A Preliminary Study

Importantly, maqasid al-Shariah is able to minimize any diversity in society by providing a means to promote integration and interaction. Chapra (2000) believe that Islamic and conventional economies are of two different things with different societies and visions are brought into play. Accordingly, the term well-being is sourced from material and hedonism in the Western world and because of that enhancement of individuals' self-interest is important including the optimising of their wealth and sensual satisfaction. Unlike this concept, the religion of Islam gives an emphasis on iqtisad or moderation, where the interest of ummah and individuals are balanced to avoid malaise and upholding social justice.

Essentially, this article intends to propose a theory that can represent a maqasid theory. It is proposed as a "Maqasid Theory of Consumer Behaviour" - MTCB. Two reasons why it is proposed. Firstly, it is a pioneering effort to promote new research to extend the theory for comparison and evaluation. Secondly, it is a pioneering effort to suggest variables capturing the theory for new debate and contribution. Furthermore, given the extant works of literature, a framework that represents the theory should capture four variables but are not confined to:

- Variable \#1:EDUCATIONAL PROGRAMME - Islam gives a key priority to disclose any information that can help consumers make a sound decision pertinent to spending, savings and consumption. The dimensions like clear advertisement and full disclosure are of importance to deliberate;

- Variable \#2: CONSUMER JUSTICE - It deals with fairness, equity and impartiality as prescribed in the primary sources;

- Variable \#3:MORTGAGE WELFARE - Like in the case of a mortgage, for instance, helping bank customers in hardship and protecting their confidentiality and interest are upheld in the Islamic business philosophy, so do Islamic banks. It addresses both financial and nonfinancial supports given to customers in need; and

- Variable \#4 - ISLAMICITY OF DEBT POLICY - It defines generally as the Shariah agreement of debt policy by the banks. Shariah is the core reason of why Islamic banks do exist. The higher the extent of Islamicity of debt policy, the better is consumer acceptance of Islamic financing products.

All in, the TMCB is a theory that is modified from maqasid al-Shariah that offers numerous benefits to banks and customers at large. From the banks' side, maqasid al-Shariah needs to represent in the structure, process and culture of the bank. The bank is expected to promote the welfare of the customer in a just and equitable manner for enhanced Islamic banking operations. In short, maqasid al-Shariah moderates the need for profit and 
Amin | Understanding Consumer Receptiveness of Mortgage-Based Islamic Social Finance Using a Maqasid Framework: A Preliminary Study

social factor for Islamic banking, in turn, promoting true Islamic banking operations. From the customers' side, the TMCB proposed provides a better prediction for the relationship between consumer behaviour and maqasid al-Shariah. The TMCB can establish new relationships that build new debates and proposing a new idea for better empirical support. The TMCB is expected to open a new spectrum of conducting research in the area of Islamic banking and finance, where the benefit it offered is greater than other theories introduced in the West, at least.

\section{Previous Studies}

Though available, studies related to four factors under contemplation are relatively fallen short. Four works, firstly by Mohammed et al. (2008), AbdulRazak and Abduh (2012), Amin et al. (2014) and Amin (2017) provide a departure.

Concerned with the educational programme for Islamic banks, Mohammed et al. (2008) have projected three items in measuring the performance of the banks. These include advancement of knowledge, instilling new skills and improvement and creating awareness of Islamic banking. The annual report is the sample used. This work discovers the Sudanese Islamic Bank (SIB) has relatively better than others in terms of the allocation of education grants. The significance of education is somehow limited when it comes to consumer perspective. The one addressed by Mohammed et al. (2008) is confined to education grants and scholarships. Due to this flaw, a work by Amin et al. (2014) extends Mohammed et al. (2008) to include consumer behaviour or consumer receptiveness. Amin et al. (2008) try to explicate it using a questionnaire survey, not intended to become as a surveyor but for the development of theory where behavioural finance comes into play. Drawing upon the maqasid al-Shariah index, this work managed to discover the significant connexion between education and consumer preference. The result obtained is fruitful that suggests education creates awareness, and awareness creates adoption.

Relating to consumer justice, these two works also outline the role that can be played by consumer justice in creating demand from mortgage products, mainly by Amin et al. (2014). This study, discovers, otherwise in which consumer justice is not related to consumer receptiveness, perhaps out of poor development of battery items used and the inability of respondents to understand the motive behind the development of the items. Earlier, Mohammed et al. (2008) used to measure justice based on fair dealings, affordable products and elimination of injustices, but their objective is not meet out of scarcity of data pertinent to justice in the operations of Islamic banks. Amin et al. (2014) though used the same approach as Mohammed et 
Amin | Understanding Consumer Receptiveness of Mortgage-Based Islamic Social Finance Using a Maqasid Framework: A Preliminary Study

al. (2008), but the battery items used are unclear, having issues on reliability and validity. Despite its flaw, the work is an eye-opener about the importance of having our own theory in consumer research.

The welfare programme in Islamic banking is also prioritised in Mohammed et al. (2008) study, proposing three items capturing welfare, namely, profitability, redistribution of income and wealth and investment in the vital real sector. Of these, Mohammed et al. (2008) find a significant effect of zakat payment by Sudanese Islamic Bank and Bank Muamalat Malaysia Berhad also play an important role in terms of zakat payment. These items somehow are mixed and no focus is directed to understand mortgage welfare rather generic capturing the general idea of Islamic banking. Due to this limitation, a work by Amin et al. (2014) takes a brave step by examining the role of welfare for Islamic home financing products although their efforts are yet proven. Evidently, however, they discover there is no significant effect that mortgage welfare can bring when a consumer intends to take up a mortgage. One of the reasons is that perhaps Islamic banks have not made mortgage welfare as an integral part of their mortgages, implying their customers clueless about it, which, in turn, can bring insignificant outcome. Not because it is not important but because it is not practised by Islamic banks seriously.

Besides these three factors, Islamic debt policy is also found important when offering the mortgage facilities. Amin (2017) discovers a significant relationship between Islamic debt policy and consumer behaviour. The reason of this outcome is based on the fact that many have been exposed about the horror stories about Islamic home financing court cases, and at the same, it is significantly contributed to the well-being of individuals since it has a long term repercussion (Abdul-Razak and Abduh, 2012). Furthermore, a work by Amin et al. (2017) examines consumer attitude and preference in the Islamic mortgage sector in Malaysia. Unlike Abdul-Razak and Abduh (2012), this study provides new thinking about examining consumer receptiveness of Islamic mortgage by considering 'our' own paradigm to understand the behaviour without being capturing by Western theories. Besides the significant roles brought by service quality and product choice, this study managed to discover the significant effect of debt policy on attitude, which in turn, affecting consumer preference. Such a significant role occurs out of the fact that the respondents involved are knowledgeable since they are university staff in which the information pertinent to Islamic mortgage is widely available and shared from one to another.

IJIEF: International Journal of Islamic Economics and Finance, 2(1), 47-72 | 54 
Amin | Understanding Consumer Receptiveness of Mortgage-Based Islamic Social Finance Using a Maqasid Framework: A Preliminary Study

\section{The Proposed Model of Mortgage-Based Islamic Social Finance (MBISF)}

As noted earlier, the model of this mortgage is based on the "intermediary" concept in which normal banking transactions are taken place. In the banking sector, sources of fund are emanated from depositors and shareholders while uses of the fund are for various types of financing products. As for the mortgage model, the sources of fund are not considered as liabilities but instead of trust from muslimfor the blessings of the Almighty. The uses of the fund are for the benefit of the mortgage in which a small monthly repayment is considered for the benefits of poor and needy. Figure 1 shows the model.

Furthermore, to make one mortgage considers as the mortgage-based Islamic social finance, some particular assumptions are needed as follows:

- Sources of funds - According to Obidullah and Shirazi (2015), based on their work on Islamic Social Finance Report (2015), Islamic social finance comprising institutions rooted in Islamic philanthropy such as zakat, awqaf and sadaqah, among others. This suggests that the proper sources of funds from the mortgage are derived mainly from zakat and awqaf. No liabilities are directly incurred. These measures indeed are growing in Malaysia;

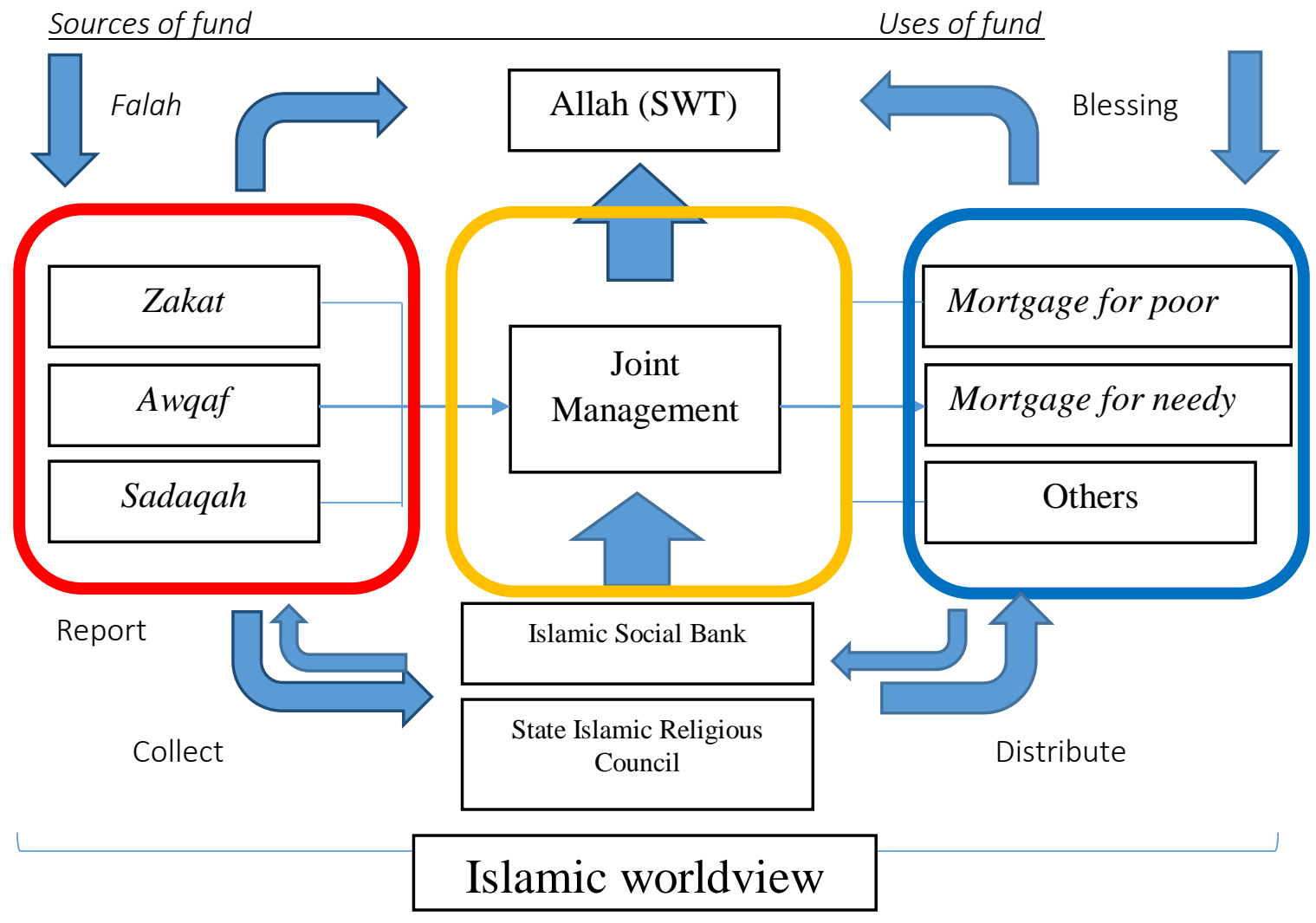

Figure 1. A Proposal of MBISF 
Amin | Understanding Consumer Receptiveness of Mortgage-Based Islamic Social Finance Using a Maqasid Framework: A Preliminary Study

- Facility providers - This mortgage should be provided by faith-based organisations, which will be mandated by the state government to work for it or federal government in matter considers its applicability. In our case, we propose "Islamic Social Bank" which has two expertise, the bank's expertise and the social's expertise (managing the needs of needy);

- Mortgage objective - The facility provided should reflect five elements of maqasidal-Shariah, viz., life, faith, mind, belongings and descendants. The mortgage offered should protect these elements otherwise it is unqualified. Explicitly, it consists of two objectives namely \#1- Financial assistance to the poor and needy for owning a better affordable house \#2 Promoting ummah's well-being through subsidised homeownership; and

- Shariah contract used - The mortgage should apply Shariah contracts to reduce the implications of debts and the ribatoo. Needless to say, bay bithamanajil (BBA), tawarruq and murabahah are Islamic financing products that encourage debt taking at losing one's debt freedom. This article, however, suggests the musharakah mutanaqisah principle in governing the operation of the mortgage promoting debt equity between the transacting parties for mardhatillah. Even better "qardhul hassan mortgage financing" but it is, however, subject to profound research and development (R\&D) before it can depart.

This proposed mortgage model helps to stimulate homeownership among poor and needy to protect their privacy and family development. It also helps to transform home-industry where the emphasis is given on a true and real mortgage as needed by society at large that brings ummatic transformation to those in need. The mortgage, however, is a mixed blessing in that it captures a specific need of those needy and poor people at the expense of other societies. Defining needy and poor people for the mortgage also requires further research for objectivity. Despite this issue, however, the current study considers as an eye-opener to improve homeownership where Islamic social finance comes into play.

Our proposed workable model here is in its infancy stage and we only aim to expose the explicit form of the model for greater work in future studies. Thus, the success of this model is relied on the smart partnership between the transacting parties (i.e. the government, society and faith-based organisation) to implement the model, where the benefits of it will be greater for greater benefits to ummah in the nation, at least.

IJIEF: International Journal of Islamic Economics and Finance, 2(1), 47-72 | 56 
Amin | Understanding Consumer Receptiveness of Mortgage-Based Islamic Social Finance Using a Maqasid Framework: A Preliminary Study

\section{Methodology}

\section{Data}

The subject of this study is young millennials who intend to buy affordable houses using Islamic home financing products. They shape the potential customer base for the mortgage and explicitly significant to generate a new customer segment that helps to create improved profitability to Islamic banks. In our context, however, affordable houses are houses that are adequate in quality, and importantly they have a reasonable price that leads to a fulfilment of homebuyers of their mortgage needs and other basic living needs. At a young age, homeownership is almost unbearable due to poor cash inflow of savings and the issue of pricing that contributes to an inability among prospective homebuyers to obtain cash financing from a bank out of a low monthly salary and skyrocketed price of the house bought.

This study was conducted in Labuan, East Malaysia in January 2019. Judgmental sampling was chosen. We select a respondent once he/she meets these criteria:

- Respondents plan to buy a property using Islamic home financing facilities;

- Respondents are millennials who are the existing customers of Islamic banks; and

- Respondents are those who support the importance of Islamic social finance including mortgage-based Islamic social finance.

We provide 300 questionnaires for data collection. Though 300 questionnaires were successfully distributed, however, only 268 questionnaires were usable for further analysis of the data. Insincere responses of 32 questionnaires were discarded. Our sample size is based on 268. The profiles of our respondents are presented in Table 1.

Table 1. Respondents' Profile

\begin{tabular}{cccc}
\hline Demographic & Detail & N & $\%$ \\
\hline Gender & Male & 126 & 47.0 \\
Education obtained & Female & 142 & 53.0 \\
& Diploma/STPM & 3 & 1.1 \\
& Degree & 165 & 61.6 \\
& Master & 72 & 26.9 \\
Marital status & PhD & 28 & 10.4 \\
& Single & 69 & 25.7 \\
& Married & 199 & 74.3 \\
\hline
\end{tabular}


Amin | Understanding Consumer Receptiveness of Mortgage-Based Islamic Social Finance Using a Maqasid Framework: A Preliminary Study

\section{Method}

We keyed in all responses using SPSS by assigning a specific code from one respondent to another. In more detail, the respondents' demographic data are analysed using descriptive statistics to elicit results of respondents' characteristic. The data keyed in using SPSS is then saved as CSV to allow PLS analyses to meet the objective of this study. Each latent variable has three (3) battery items equally to allow a better comparison between factors analysed by understanding their significance level to the model of this work. At least two reasons why PLS are selected. Firstly, PLS allows a theory development when a new factor in added to the formation of a research model like occurs in this present study (Amin, 2017). Secondly, PLS demands minimally on scales used, sample size and residual distributions (Chin et al., 2003). The present work suggests new battery items representing a framework, allowing their compatibility with the research hypotheses.

Following Churchill Jr. (1979), we develop the research items using two approaches, firstly literature analyses, and, secondly expert feedback. As for the former, all battery items developed are adapted from previous studies related. The detail descriptions are provided as follows:

Educational programme - Three items of this variable are modified from Mohammed et al. (2008) and Billah (2006). These studies have defined "education" differently. Mohammed et al. (2008) decompose it to include education grants/donation, research, training and publicity whilst Billah (2006) refers it as knowledgeable persons. We modify these items to generate these battery items:

- I consider a bank that provides mortgage's educational programme;

- I consider a bank that provides publicity on Islamic home financing; and

- I consider a bank that provides adequate adverts.

Mortgage welfare - Three items of this variable are modified from Haniffa and Hudaib (2007) and JabatanSyariah BMMB (2012) and Amin (2015). Emanating from these works, we create these items:

- I consider a bank that protects customers' interest;

- I consider a bank that provides a mortgage to needy and poor people; and

- I consider a bank that extends its value-based intermediation to existing and new customers.

Consumer justice - Three items of this variable are adapted from Amin (2015). Deriving from this work, these three items are developed:

- I consider a bank that avoids disputes;

- I consider a bank that acts justly to customers; and

- I consider a bank that avoids a dubious financial contract.

IJIEF: International Journal of Islamic Economics and Finance, 2(1), 47-72 | 58 
Amin | Understanding Consumer Receptiveness of Mortgage-Based Islamic Social Finance Using a Maqasid Framework: A Preliminary Study

Islamic debt policy - Three items of this variable are adapted from Amin (2017) and Haniffa and Hudaib (2007). The details are as follows

- I consider a bank with an Islamic debt policy;

- I consider a bank that offers me an Islamic debt restructuring; and

- I consider a bank that offers me an Islamic rescheduling.

All items are adapted out of the fact that earlier studies have developed their battery items to capture a context of Islamic home financing in Malaysia. After the generation of items, we invite 5 Shariah scholars to review and to comment on the research items. With all considerations, only a small revision is conducted. The items are measured using a 5-Likert scale ranging from a low response of strongly disagree [1] to a high response of strongly agree [5].

As for face validity, a pilot test was conducted among 30 respondents in which the battery items were corrected and improved accordingly. The finalised questionnaire was sent for an actual survey to elicit responses and feedback.

\section{Model Development}

Our MTCB is based on four latent variables namely educational programme, mortgage welfare, consumer justice and Islamic debt policy. Each of these variables generates three battery items for better operationalisations (Churchill Jr., 1979). We build up a relationship between educational programme and receptiveness based on Mohammed et al. (2008) and Billah (2006). The educational programme is important as it creates consciousness and public confidence for the formation of patronage. Hence, the higher the extent of the educational programme, the better is the consumer receptiveness. Likewise, the relationship we establish between mortgage welfare and consumer receptiveness is based on Haniffa and Hudaib (2007) and Jabatan Syariah BMMB (2012) and Amin (2015). Mortgage welfare is important owing to these reasons. Firstly, mortgage welfare is important to protect the interest of customers via financial counselling and secondly the bank is offering continuous support (e.g. payment holiday) after the patronage mainly when the customers are encountered with financial hardship. Consequently, the higher the extent of mortgage welfare, the better is the consumer receptiveness. 
Amin | Understanding Consumer Receptiveness of Mortgage-Based Islamic Social Finance Using a Maqasid Framework: A Preliminary Study

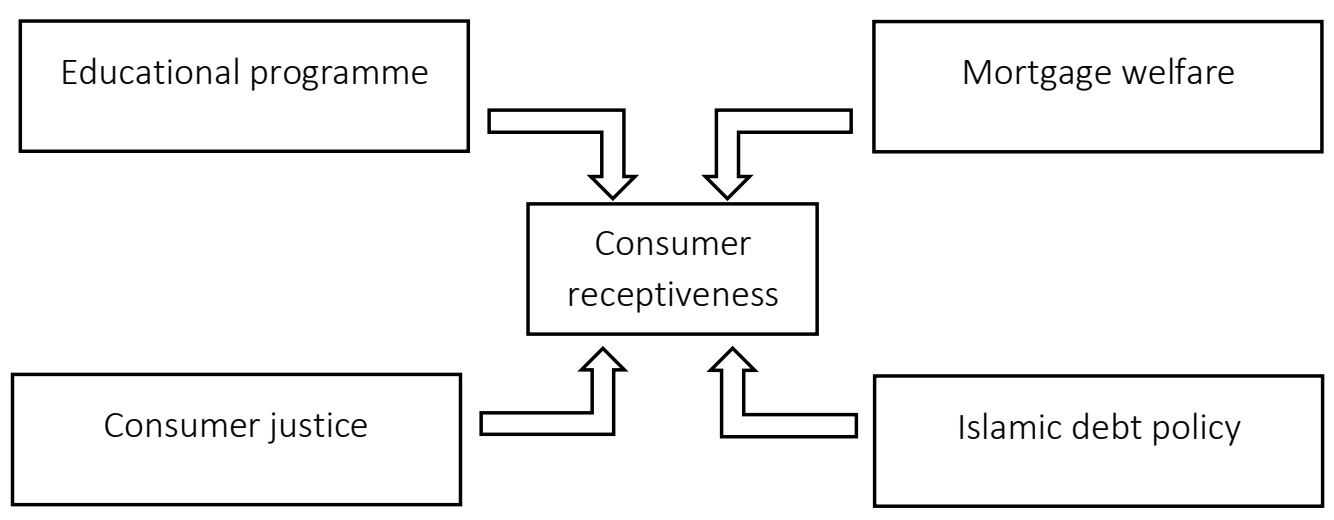

Figure 2. The Research Model

Likewise, we propose a relationship between consumer justice and consumer receptiveness by extending a work by Amin (2015) meticulously. This work expounds five battery items to capture consumer justice but in this current work, we examine three only for relevancy. These constitute the act of avoiding disputes, the act of fairness and the act of preventing dubious financial contracts. This variable is essential because it creates a value-added facility that protects the interest of customers when they patronising the facility. Thus, the higher the extent of consumer justice, the better is the consumer receptiveness.

Furthermore, a relationship between Islamic debt policy and consumer receptiveness is also proposed. Debt policy should be 'Islamic' to allow better patronage of customers with their financial capacity at the expense of self-interest and no performing financing. This variable is significant owing to the fact that Islamic debt policy allows a debt treatment Islamically to debtors who are facing financial hardships at the expense of acute indebtedness. Amin (2017) and Haniffa and Hudaib (2007) assert the significance of having an Islamic way of treating debtors to improve public perception, allowing a new formation of consumer receptiveness mainly by millennials. Accordingly, the higher the extent of consumer justice, the better is the consumer receptiveness.

On the basis of these avowals, I propose four alternative hypotheses to validate the relationships exist between four independent variables and a dependent variable. The details are provided.

- H1: There is a significant relationship between the educational programme and consumer receptiveness (Mohammed et al., 2008 \& Billah, 2006);

- $\quad H 2$ : There is a significant relationship between mortgage welfare and consumer receptiveness (Haniffa \& Hudaib, 2007; Jabatan Syariah BMMB, 2012); 
Amin | Understanding Consumer Receptiveness of Mortgage-Based Islamic Social Finance Using a Maqasid Framework: A Preliminary Study

- H3: There is a significant relationship between consumer justice and consumer receptiveness (Amin, 2015); and

- H4: There is a significant relationship between Islamic debt policy and consumer receptiveness (Amin, 2017; Haniffa \& Hudaib, 2007).

\section{Results and Analysis}

In analysing the data, two stages of the data analysis are conducted, namely, measurement model that describes factor loadings, reliability and discriminant validity and structural analysis that describes the effects of the variables tested on the receptiveness. The details are provided as follows:

\section{Results}

\section{Measurement model}

In this work, our analysis is conducted using a two-stage approach (Chin, 2010). The approach includes measurement model and structural analysis, in which the former is conducted to examine the validity and reliability of the model developed whilst the latter is conducted to evaluate the pattern and significance of the relationship between one variable to another. Likewise, Table 2 presents the factor loadings for all battery items under contemplation. It is found out that all items that hypothesised to represent their own particular factor/variable are statistically significant and loaded highly in the factor that they supposed to measure. Besides, no battery items loaded higher on the factor that they are not hypothesised to gauge. Following Churchill Jr (1979), factor loadings are important in discriminating valid items from non-valid items for a specific factor that they measure. Given our results, we conclude that all battery items analysed are valid and taken up for further analysis of the data.

IJIEF: International Journal of Islamic Economics and Finance, 2(1), 47-72 | 61 
Amin | Understanding Consumer Receptiveness of Mortgage-Based Islamic Social Finance Using a Maqasid Framework: A Preliminary Study

Table 2. Factor Loadings

\begin{tabular}{cccccc}
\hline Item & IDP & CR & EP & CJ & MW \\
\hline IDP1 & 0.883 & 0.413 & 0.139 & 0.400 & 0.494 \\
IDP2 & 0.919 & 0.424 & 0.203 & 0.549 & 0.446 \\
IDP3 & 0.893 & 0.432 & 0.149 & 0.499 & 0.339 \\
CR1 & 0.485 & 0.953 & 0.380 & 0.333 & 0.544 \\
CR2 & 0.425 & 0.935 & 0.335 & 0.445 & 0.434 \\
CR3 & 0.411 & 0.884 & 0.206 & 0.434 & 0.484 \\
EP1 & 0.221 & 0.331 & 0.944 & 0.294 & 0.139 \\
EP2 & 0.184 & 0.301 & 0.938 & 0.205 & 0.144 \\
EP3 & 0.133 & 0.243 & 0.892 & 0.253 & 0.194 \\
CJ1 & 0.433 & 0.492 & 0.240 & 0.934 & 0.446 \\
CJ2 & 0.531 & 0.301 & 0.223 & 0.935 & 0.519 \\
CJ3 & 0.523 & 0.305 & 0.248 & 0.890 & 0.493 \\
MW1 & 0.424 & 0.433 & 0.205 & 0.491 & 0.915 \\
MW2 & 0.382 & 0.484 & 0.131 & 0.384 & 0.922 \\
MW3 & 0.235 & 0.484 & 0.131 & 0.433 & 0.832 \\
\hline
\end{tabular}

Note: IDP=Islamic debt policy, $C R=$ Consumer receptiveness, EP=Educational programme, $\mathrm{CJ}=$ Consumer justice, $\mathrm{MW}=$ Mortgage welfare.

We also run several tests covering AVE, composite reliability (CR) and Cronbach's alpha for reliability. Our AVE values are also greater than the recommended value of 0.5 . These results are in tandem with Fornell and Larcker (1981) proposal in which AVE values that greater than 0.5 are meeting the convergent validity. All factors tested have produced acceptable values for $\mathrm{CR}$, exceeding the threshold value of 0.7 and for that all items capturing the factors are reliable. Furthermore, our Cronbach's alpha test also reveals favourable outcomes in which all constructs' items have produced the intended value of greater than the threshold of 0.6. This concludes the battery items representing the constructs are having adequate internal consistency.

Table 3. Reliability

\begin{tabular}{lllll}
\hline Factor & AVE & Composite Reliability & R Square & Cronbach's Alpha \\
\hline IDP & 0.807 & 0.926 & - & 0.881 \\
EP & 0.869 & 0.952 & - & 0.925 \\
CJ & 0.848 & 0.944 & - & 0.910 \\
MW & 0.817 & 0.930 & - & 0.889 \\
CR & 0.855 & 0.946 & 0.687 & 0.915 \\
\hline
\end{tabular}

Note: IDP=Islamic debt policy, $C R=$ Consumer receptiveness, $E P=$ Educational programme, $\mathrm{CJ}=$ Consumer justice, $\mathrm{MW}=$ Mortgage welfare. 
Amin | Understanding Consumer Receptiveness of Mortgage-Based Islamic Social Finance Using a Maqasid Framework: A Preliminary Study

Furthermore, Table 4 presents the results pertaining to the discriminant validity. All values examined for the respective factors are greater than the threshold value of 0.7 , implying there exists the discriminant validity for the factors under contemplation. Our results are in line with Fornell and Larcker's (1981) proposal, in which they assert that the discriminant validity established when the square root of the AVE for the given factor is greater than the correlation shared with other factors under consideration. The details of this assertion are given in Table 4.

Table 4. Discriminant Validity

\begin{tabular}{llllll}
\hline Factor & IDP & EP & CH & MW & CR \\
\hline IDP & 0.899 & & & & \\
EP & 0.199 & 0.932 & & & \\
CJ & 0.311 & 0.273 & 0.921 & & \\
MW & 0.497 & 0.192 & 0.380 & 0.904 & \\
CR & 0.395 & 0.335 & 0.360 & 0.421 & 0.925 \\
\hline
\end{tabular}

Note: IDP=Islamic debt policy, $C R=$ Consumer receptiveness, EP=Educational programme, $\mathrm{CJ}=$ Consumer justice, $\mathrm{MW}=$ Mortgage welfare.

\section{Structural Analysis}

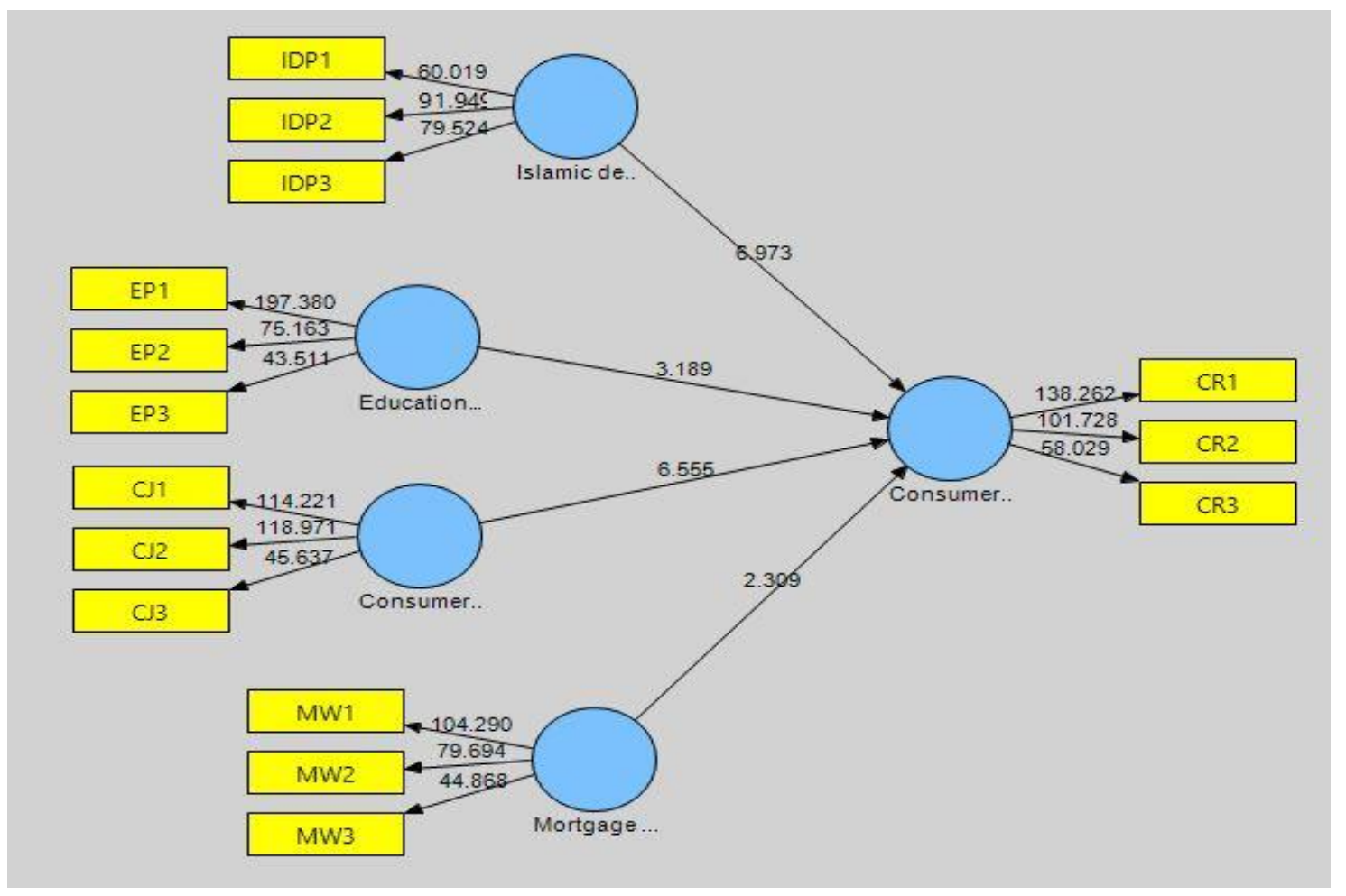

Figure 3. The Analysed Research Model 
Amin | Understanding Consumer Receptiveness of Mortgage-Based Islamic Social Finance Using a Maqasid Framework: A Preliminary Study

Table 5. Structural Analysis

\begin{tabular}{lllll}
\hline Pathway & Beta & SD & t-value & Supported \\
\hline $\mathrm{CJ} \rightarrow \mathrm{CR}$ & 0.420 & 0.063 & 6.555 & Yes \\
$\mathrm{EP} \rightarrow \mathrm{CR}$ & 0.125 & 0.038 & 3.189 & Yes \\
$\mathrm{IDP} \rightarrow \mathrm{CR}$ & 0.343 & 0.050 & 6.973 & Yes \\
$\mathrm{MW} \rightarrow \mathrm{CR}$ & 0.141 & 0.061 & 2.309 & Yes \\
\hline Note: IDP=Islamic debt & policy, & CR=Consumer & receptiveness, & EP=Educational programme, \\
CJ=Consumer justice, MW=Mortgage welfare.
\end{tabular}

The results obtained as reported in Table 5 suggest that consumer justice has the highest influence on consumer acceptance ( $B=0.420 \& t=6.555)$ followed by Islamic debt policy ( $\beta=0.343 \& \mathrm{t}=6.973$ ). This finding indicates that bank customers intend to take up the mortgage when the treatment emanated from the mortgage is fair and it is accessible to all layers of individuals in our society. This element needs to be included in the mortgage model. This finding also indicates that bank customers will consider Islamic debt policy when they are satisfying the fair treatment that comes without discrimination to prospective customers. The respondents are also believing that consumer justice and Islamic debt policy is somehow related in which the latter is part of the former. Regardless of these, banks that offer actual Islamic debt treatments can be potential to be patronised by bank customers.

Likewise, the results also suggest that mortgage welfare has a higher influence on consumer receptiveness $(B=0.141 \& \mathrm{t}=2.309)$ than educational programme $(\beta=0.125 \& t=3.189)$. The reasons are two-fold. The results reveal that mortgage welfare is greater than an educational programme since the former has a direct influence when one decides to take up the mortgage than that of the latter. Individuals could have been expected to react mostly because of the packages of welfare provided by service providers. If the welfare programme is accessible and available, one tends to opt it first before the educational programme comes into play. The educational programme is only considered when it is relevant and has a direct input to make a decision to take up the mortgage facility.

To sum up, all proposed hypotheses are validated empirically and found to be statistically significant and related, implying the present research framework is acceptable.

IJIEF: International Journal of Islamic Economics and Finance, 2(1), 47-72 | 64 
Amin | Understanding Consumer Receptiveness of Mortgage-Based Islamic Social Finance Using a Maqasid Framework: A Preliminary Study

\section{Analysis}

As for the first hypothesis, we managed to discover that there is a significant relationship between the educational programme and consumer receptiveness, in which the relationship is of positive, implying the higher the extent of the educational programme, the better is the receptiveness. This result is tandem with Mohammed et al. (2008) and Billah (2006), extending their findings on the significance of education to the current research. Why it is significant? With an improved educational programme, one's confidence is improved for better acceptance of the mortgage facility. With knowledge, consumer confidence is improved.

In terms of the second hypothesis, mortgage welfare is also demonstrated to be statistically related to consumer receptiveness and the relationship found is positive. This means, the higher the extent of mortgage welfare, the better is the acceptance. This finding is in light with assertions by Hanifa and Hudaib (2007) and Jabatan Syariah BMMB (2012), denoting mortgage welfare and the mortgage facility are related. Perhaps, it is explicitly argued that mortgage welfare is an essential component in the maqasid, and also an objective of the mortgage facility to jack up the preservation of interest of homebuyers mainly those who are millennials (needy and poor people).

The relationship between consumer justice and consumer receptiveness is also fruitful and has a greater impact compared with other variables. This work confirms an earlier finding by Amin (2015) who claims the formation of patronage is due to consumer justice. Consumer justice enables the promotion of Shariah compliance to the transacting parties, where maslahah to bankers and customers are upheld accordingly. It can become like a competitive advantage to improve its discrepancy compared with existing Islamic home financing products. We find a positive relationship between consumer justice and consumer receptiveness, suggesting when consumer justice is upheld by the bank, consumer willingness to take up the facility is improved accordingly.

On the same note, the same trend of finding is also found to a relationship between Islamic debt policy and consumer receptiveness. This finding is supported by Amin (2017) and Haniffa and Hudaib (2007) and one of the possible reasons is that debt policy is an important element in the financial transaction between a debtor and a creditor as promoted in the primary sources (i.e. The Quran and the Hadith). Amin (2017) examines the possible influence of Islamic debt policy on existing Islamic home financing products and its outcome is of significance. Our finding is in tandem with this work since our battery items are taken from Amin (2017), indicating that there exists an element of compatibility between the present work and Amin (2017). We also find that the present finding is in consonance with Haniffa

IJIEF: International Journal of Islamic Economics and Finance, 2(1), 47-72 | 65 
Amin | Understanding Consumer Receptiveness of Mortgage-Based Islamic Social Finance Using a Maqasid Framework: A Preliminary Study

and Hudaib (2007) due to a proper conceptualisation, which is done on the basis of cognitive. More importantly, our finding is significant and it's in light with Amin (2017) and Haniffa and Hudaib (2007) because of our study finding support on debt cancellation, debt forgiveness and Islamic debtors' treatment as operationalised accordingly in the present work.

\section{Conclusion and Recommendation}

\section{Conclusion}

The results obtained suggest that consumer justice, Islamic debt policy, mortgage welfare and educational programme determine consumer receptiveness. In other words, consumers show positive perceptions regarding the ability of justice, Islamic debt policy, mortgage welfare and educational programme to meet their financial mortgage needs. As a result, banks can provide sufficient information about these factors to potential consumers, which may function as a reliable source of information and can help them to make a sound decision. Though websites of Islamic banks are essential, somehow, the reliability of the websites is dependent on how often the banks update the information available on websites. As such, a constant update at least for every 5 minutes can be of help to improve the relevance and usefulness of mortgage facilities offered. In more detail, we provide the following contributions:

\section{Theoretical contributions}

This work introduces a new framework that captures the effects of consumer justice, Islamic debt policy, mortgage welfare and educational programme on consumer receptiveness. Our empirical findings indicate that these factors are statistically significant and for that, the hypothesised hypotheses are found valid. On the same note, the maqasid framework is also found relevant and for that, it is a new measure that can be employed for future studies, where Islamic banking products and services are brought into play. Another theoretical contribution of the current study is the inclusion of customer perceptions of the factors involved based on the cognitive belief evaluations, which in turn, can deliver valuable insights into potential home buyers' cognitive processes. On the same note, this study also makes a substantial contribution to the body of knowledge by reducing the gaps in consumer mortgage behaviour/receptiveness. More importantly, this work provides empirical support for the factors under contemplation to explicate consumer receptiveness in the context of MBISF.

IJIEF: International Journal of Islamic Economics and Finance, 2(1), 47-72 | 66 
Amin | Understanding Consumer Receptiveness of Mortgage-Based Islamic Social Finance Using a Maqasid Framework: A Preliminary Study

\section{Methodological contributions}

Our study here provides also a methodological contribution pertinent to the development of constructs' items related to consumer justice, Islamic debt policy, mortgage welfare and educational programme on consumer receptiveness. We find no specific battery items that represent these factors. We build up the items by examining some ideas expressed by earlier works (e.g. Billah, 2006; Haniffa and Hudaib, 2007; Mohammed et al., 2008; JabatanSyariah BMMB, 2012).The measurement scales are developed specifically by eliciting responses by five Shariah scholars, who are pious and knowledgeable on mortgage facilities. In this study, each factor proposed has three battery items and consistently applied to other factors and further, they are enhanced through interviews with Shariah scholars as well as a pilot test involving 30 respondents (not reported in this study). Yet, the battery items develop can also be employed and to be generalised into other Islamic banking products without confining themselves to Islamic home financing products, alone.

\section{Practical contributions}

This study generally provides a general guideline on how to improve consumer receptiveness using so-called Islamic yardsticks. In their marketing, managers of the mortgage in should pay attention to the fairness of the financial treatments, related to consumer justice and Islamic debt policy. The factors recognised in this study can determine consumer receptiveness and allow managers of Islamic social bank to focus on developing better plans to improve visibility and thus demand. This indicates that our findings are not only served as a source of reference but also can act as a directive that can be fully optimised to strengthen the marketing strategies should Islamic social bank introduce. All taken, our findings are able to educate mortgage managers even to existing Islamic bank about how to maintain the competitive advantage of Islamic home financing products through the inclusion of zakat, waqf and sadaqah.

Likewise, no studies can immune from any limitations and the same goes to the present study. We outline two main limitations to drive future works in this area:

- Firstly, this work is confined to Labuan, a specific city presently accessible in Malaysia that can explicate its limitations and so do its contribution to the body of knowledge. Results obtained may not be fully generalisable to include other bank customers from untested market segments. Future works may learn on how to cover the 
Amin | Understanding Consumer Receptiveness of Mortgage-Based Islamic Social Finance Using a Maqasid Framework: A Preliminary Study

geographies to include Indonesia, Brunei and Philippines to extend the research findings; and

- Secondly, our contributions are confined to the variables under contemplations, in which only four factors are proven to be essential to predict consumer receptiveness of mortgage. Our PLS model presents 68.7 per cent of the variances explained in the consumer receptiveness, implying about 31.3 per cent of its variances are drawn from other factors, not tested in the present model.

Despite these flaws, the present study provides us with an improved understanding about a framework that explicates consumer receptiveness of mortgage-based Islamic social science and perhaps this work can become as a source of reference to guide more academic research by academicians and action research by practitioners pertinent to the feasibility of the mortgage implementation.

\section{Recommendations}

This work provides direction on how to promote MBISF in the Islamic banking industry, mainly in Malaysia. As such, we offer some recommendations to the practitioner (Islamic bank), regulator, and academician.

- Islamic banks that intend to offer this mortgage facility needs to set up a special workforce to carry out research before departing for the offer of the facility. Objectives, Shariah contracts and targeted customers should be understood before others can take place. Importantly, Islamic banks should ensure that the starting point and direction are defined correctly. It would be difficult to change once it offers to the public at large. For that, educational programme, consumer justice, mortgage welfare and Islamic debt policy need to be included;

- Regulators mainly Bank Negara Malaysia can develop a smart collaboration with state governments and Islamic banks by firstly developing a directive, a guideline and a product disclosure of the mortgage facility to guide state government and Islamic banks in implementing the facility gradually; and

- Academicians may change their direction of research by developing their own Islamic theories to study consumer behaviours where maqasid al-Shariah is brought into play. Yet, academicians from other geographies can think of expanding the horizon of this work to other countries to extend the findings. It might be worthy to consider Indonesia, Brunei, Thailand and the Philippines and even 
Amin | Understanding Consumer Receptiveness of Mortgage-Based Islamic Social Finance Using a Maqasid Framework: A Preliminary Study

better to perform a comparative study of consumer behaviour of MBISF.

Indeed, this study provides a new perceptive to researchers to guide their consumer behaviour studies related to Islamic banking products. It is intended to reduce their reliance on conventional consumer theories to avoid further extension of Westernisation of Knowledge of Islamic banking products. Yet, if daruriyyat established, some exceptions can be considered. Allah (SWT) knows best.

\section{Acknowledgement}

This study is funded by the Fundamental Research Grant Scheme (FRGS): FRG0438-SS-1/2016, Ministry of Higher Education (MOHE), Malaysia. 
Amin | Understanding Consumer Receptiveness of Mortgage-Based Islamic Social Finance Using a Maqasid Framework: A Preliminary Study

\section{References}

Al-Quran, (1997). English Translation of the Meaning of Al-Quran, translated from Arabic by Muhammad Farooq-i-Azam Malik Houston, Texas, U.S.A: The Institute of Islamic Knowledge.

Abdul-Razak, D., \& Abduh, M. (2012). Customers' attitude towards diminishing partnership home financing in Islamic banking. American Journal of Applied Sciences, 9(4), 593-599.

Amin, H., Abdul-Rahman, A. R., \& Abdul Razak, D. (2014). Theory of Islamic consumer behaviour: An empirical study of consumer behaviour of Islamic mortgage in Malaysia. Journal of Islamic Marketing, 5(2), 273301.

Amin, H. (2015). Consumer preference and behaviour of Islamic home financing: a study of potential home buyers in Malaysia. Unpublished PhD Thesis, Kuala Lumpur: IIUM Institute of Islamic Banking and Finance.

Amin, H. (2017). Consumer behaviour of Islamic home financing: Investigating its determinants from the theory of Islamic consumer behaviour. Humanomics, 33(4), 517-548.

Auda, J. (2008). MaqasidAl-Shariahas Philosophy OfIslamic Law: A System Approach. London: The International Institute of Islamic Thought.

Bank Negara Malaysia (2018). Key financial indicators: Islamic banking and takaful sectors. Accessed on 22nd June 2019 at http://www.bnm.gov.my/index.php?ch=en publication\&pg=en fspr\&a $\mathrm{c}=27$ \&en

Billah, M. M. (2006). Shar'iah Standard of Business Contract. Kuala Lumpur: A.S. Noordeen.

Chapra, M. U. (1992). Islam and The Economic Challenge(No. 17). International Institute of Islamic Thought (IIIT).

Chapra, M. U. (2000). The Future of Economics: An Islamic Perspective. United Kingdom: The Islamic Foundation.

Chin, W. W. (2010). How to write up and report PLS analyses. In Vinzi, V.E., Chin, W.W., Henseler, J., \& Wang, H. (eds.), Handbook of Partial Least Squares. (pp. 655-690). Berlin, Germany: Springer-Verlag.

Choudhury, M. A. (1986). Contributions to Islamic Economic Theory: A Study in Social Economics. New York: St Martin's Press.

Churchill, Jr, G. A. (1979). A paradigm for developing better measures of marketing constructs. Journal of Marketing Research, 16(1), 64-73.

Department of Statistics Malaysia. (2016). Report on Household Income and Basic Amenities Survey 2016. Accessed on 28th March 2019 at https://www.dosm.gov.my/v1/index.php?r=column/cthemeByCat\&cat= 120\&bul_id=RUZ5REwveU1ra1hGL21JWVIPRmU2Zz09\&menu_id=amVo WU54UTI0a21NWmdhMjFMMWcyZz09.

Dusuki, A. W. (2008). Understanding the objectives of Islamic banking: A survey of stakeholders' perspectives. International Journal of Islamic and Middle Eastern Finance and Management, 1(2), 132-148.

Fornell, C., \& Larcker, D. F. (1981). Evaluating structural equations models with unobservable variables and measurement error. Journal of Marketing Research, 18(1), 39-50.

Hasan, Z. (2011). Islamic home finance in the social mirror. ISRA International Journal of Islamic Finance, 3(1), 7-24.

IJIEF: International Journal of Islamic Economics and Finance, 2(1), 47-72 | 70 
Amin | Understanding Consumer Receptiveness of Mortgage-Based Islamic Social Finance Using a Maqasid Framework: A Preliminary Study

Haniffa, R., \& Hudaib, M. (2007). Exploring the ethical identity of Islamic banks via communication in annual reports. Journal of Business Ethics, 76(1), 97-116.

Jabatan Syariah BMMB. (2012). Etika/tanggungjawab bank dalampembiayaan. Al-Muamalat,6, 4-15.

Kamali, M. H. (2008). MaqasidAl-ShariahMade Simple. London: The International Institute of Islamic Thought.

Mydin-Meera, A. K., \& Abdul-Razak, D. (2005). Islamic home financing through musharakahmutanaqisah and al-Bay' BithamanAjil contracts: a comparative analysis. Review of Islamic Economics, 9(2), 5-30.

Mohammed, M. O., Abdul-Razak, D., \& Md-Taib, F. (2008). The Performance Measures of Islamic Banking on theMaqasid Framework. Paper presented at IIUM International Accounting Conference (INTAC IV), organised by International Islamic University Malaysia, Putra Jaya.

Muneeza, A., Hassan, R., \& Wisham, I. (2011). Islamic Banking under the Malaysia Law. Kuala Lumpur: A.S. Noordeen.

Obidullah, M., \& Shirazi, N. S. (2015). Islamic Social Finance Report. (2015). Jeddah: Islamic Research and Training Institute (IRTI).

Richardson, E. (2011). Islamic finance for consumers in Ireland: a comparative study of the position of retail-level Islamic finance in Ireland. Journal of Muslim Minority Affairs, 31(4), 534-553.

Rosly, S. A. (2010). Shariahparameters reconsidered. International Journal of Islamic and Middle Eastern Finance and Management, 3(2), 132-146.

Zabri, M., Md, Z., Abdul Razak, D., \& Mohammed, M. O. (2015). An analytical framework to examine Shari'ah-compliant mortgage financing by financial cooperatives in Malaysia. Journal of Islamic Finance, 176(3132), 1-13.

Zabri, M. Z. M., \& Mohammed, M. O. (2018). Examining the behavioural intention to participate in a Cash Waqf-Financial CooperativeMusharakah Mutanaqisah home financing model. Managerial Finance, 44(6), 809-829. 
Amin | Understanding Consumer Receptiveness of Mortgage-Based Islamic Social Finance Using a Maqasid Framework: A Preliminary Study

This page is intentionally left blank

IJIEF: International Journal of Islamic Economics and Finance, 2(1), 47-72 | 72 